\title{
Status mutu air Kali Angke di Bogor, Tangerang, dan Jakarta
}

\author{
S. R. Oktavia ${ }^{1 *}$, H. Effendi ${ }^{2}$, S. Hariyadi ${ }^{1}$ \\ ${ }^{1}$ Departemen Manajemen Sumberdaya Perairan, Institut Pertanian Bogor, Bogor, Indonesia \\ 2Pusat Penelitian Lingkungan Hidup, Institut Pertanian Bogor, Bogor, Indonesia
}

\begin{abstract}
Abstrak.
Masuknya bahan-bahan pencemar ke dalam badan air sungai menyebabkan turunnya kualitas air sungai. Salah satu sungai yang diduga telah mengalami pencemaran adalah Kali Angke. Penelitian ini bertujuan untuk menentukan status mutu air dan tingkat pencemaran Kali Angke menggunakan metode Indeks Pencemaran (IP) dan Indeks Canadian Council of Minister of The Environment (CCME). Pengambilan data kualitas air dilakukan pada lima segmen sebanyak 21 titik pengambilan contoh pada tanggal 2-4 Oktober 2017. Data sekunder kualitas air berasal dari Dinas Lingkungan Hidup Kota Bogor, Kabupaten Bogor, Tangerang Selatan, Tangerang, dan Jakarta Barat. Parameter kualitas air meliputi parameter fisika (suhu, TSS, dan TDS), parameter kimia (DO, BOD, COD, $\mathrm{NO}_{2}-\mathrm{N}, \mathrm{NO}_{3}-\mathrm{N}, \mathrm{pH}$, total fosfat, $\mathrm{Zn}$, minyak lemak, $\mathrm{Hg}$, dan $\mathrm{Cu}$ ), dan parameter biologi (fecal coliform dan total coliform). Indeks kualitas air CCME lebih mewakili kondisi perairan daripada Indeks Pencemaran. Tingkat pencemaran semakin meningkat dari hulu ke hilir dan dari tahun 2014 sampai 2016, kemudian menurun pada tahun 2017. Status mutu Kali Angke tergolong cemar ringan menurut IP dan tergolong buruk menurut Indeks CCME.
\end{abstract}

Kata kunci: indeks CCME, indeks pencemaran, kualitas air

\begin{abstract}
.
The entry of pollutants into river leads to a decrease in river water quality. One of the river that has been polluted is Angke River. This study aimed to determine the status of water quality and pollution levels of Angke River based on pollution index (IP) and Canadian Council of Ministers of The Environment (CCME). Water quality data collection was conducted in five segments of 21 sampling points on 2-4 October 2017. Water quality secondary data came from Environmental Agency of Bogor City, Bogor District, South Tangerang, Tangerang and West Jakarta. Water quality parameters included physical parameters (temperature, TSS, and TDS), chemical parameters (DO, BOD, COD, $\mathrm{NO}_{2}-\mathrm{N}$, $\mathrm{NO}_{3}-\mathrm{N}, \mathrm{pH}$, total phosphate, $\mathrm{Zn}$, oil and grease, $\mathrm{Hg}$, and $\mathrm{Cu}$ ), and biological parameters (fecal coliform and total coliform). The CCME air quality index was more representative of aquatic conditions than Pollution Index. The level of pollution increased from upstream to downstream from 2014 to 2016, then decreased in 2017. The quality status of Angke River was classified as lightly polluted according to IP and classified as marginal according to the CCME Index.
\end{abstract}

Keywords: CCME index, pollution index, water quality

\section{PENDAHULUAN}

Air merupakan sumber daya alam yang diperlukan untuk hajat hidup orang banyak, bahkan oleh semua makhluk hidup. Salah satu sumber air bagi manusia adalah sungai. Sungai merupakan salah satu ekosistem perairan mengalir yang berperan penting dalam menunjang kegiatan dan kehidupan manusia (Pasisingi et al. 2014). Sungai memiliki peran strategis secara ekonomi bagi masyarakat dan pembangunan daerah, seperti sumber air minum, bahan baku industri, sarana budi daya perikanan, irigasi pertanian, dan pembangkit tenaga listrik daerah (Imroatushshoolikhah et al. 2014). Sungai terbagi menjadi tiga bagian yaitu hulu, tengah dan hilir.

Air sungai di bagian hulu pada umumnya memiliki kualitas air yang lebih baik dari pada daerah hilir. Hal tersebut karena pemanfaatan lahan di daerah hulu relatif sederhana dan bersifat alami, seperti hutan dan perkampungan kecil.

\footnotetext{
${ }^{*}$ Korespondensi Penulis

Email : rosaoktavia303@gmail.com
} 
Semakin ke arah hilir keragaman pemanfaatan lahan menjadi meningkat, sehingga air sungai akan menerima berbagai macam bahan pencemar (Wiwoho 2005). Masuknya bahan-bahan pencemar ke dalam air sungai menyebabkan turunnya kualitas air sungai.

Suatu sungai dikatakan mengalami penurunan kualitas air, jika sungai tersebut tidak dapat digunakan sesuai dengan status mutu air secara normal (Ali et al. 2013). Status mutu air yang dimaksud adalah tingkat kondisi mutu air yang menunjukkan kondisi cemar atau kondisi baik pada suatu sumber air dalam waktu tertentu dengan membandingkan pada baku mutu air yang ditetapkan (KepMenLH Nomor 115 Tahun 2003). Status mutu air sungai di Indonesia sebagian besar dalam kondisi cemar, terutama setelah melewati daerah pemukiman, industri dan pertanian.

Kali Angke merupakan salah satu sungai yang diduga telah mengalami pencemaran. Kali Angke berhulu di Bogor, Jawa Barat, kemudian melewati Tangerang Selatan di Kota Tangerang, dan bermuara di Muara Angke, Jakarta Barat. Nama Angke berasal dari dialek Hokkian, yang berarti Kali Merah. Kali Angke dijadikan sebagai tempat pembuangan limbah, baik domestik maupun industri yang umumnya tanpa mengalami pengolahan terlebih dahulu (Cordova dan Riani 2011).

Penelitian sebelumnya di Kali Angke pernah dilakukan oleh Tjampakasari and Wahid (2008) serta Cordova and Riani (2011). Akan tetapi, penelitian tersebut hanya menganalisis kualitas air dari aspek mikrobiologi dan logam berat di bagian hilir sungai. Penelitian mengenai status mutu air di Kali Angke dari bagian hulu hingga hilir masih belum banyak dilakukan. Oleh karena itu, perlu dilakukan penelitian mengenai status mutu air Kali Angke dari hulu hingga hilir. Informasi mengenai status mutu air Kali Angke diperlukan sebagai landasan dalam pengelolaan di Kali Angke. Penelitian ini bertujuan menentukan status mutu air dan tingkat pencemaran Kali Angke menggunakan metode Indeks Pencemaran (IP) dan Indeks Canadian Council of Minister of the Environment (CCME).

\section{METODOLOGI}

\subsection{Lokasi kajian dan waktu penelitian}

Pengambilan contoh dilakukan pada tanggal 2-4 Oktober 2017. Data parameter fisika dan kimia air berasal dari pengambilan contoh air di Kali Angke meliputi Kabupaten Bogor, Kota Bogor, Tangerang Selatan, Tangerang, dan Jakarta Barat, sebanyak 21 titik pengambilan contoh (Gambar 1 dan Tabel 1). Analisis parameter kualitas air dilakukan di Laboratorium Lingkungan, Pusat Penelitian Lingkungan Hidup, Institut Pertanian Bogor. Data sekunder diperoleh 
dari Dinas Lingkungan Hidup (DLH) Kabupaten Bogor, Kota Bogor, Kota Tangerang, Kota Tangerang Selatan, dan DKI Jakarta tahun 2014, 2015 dan 2016.

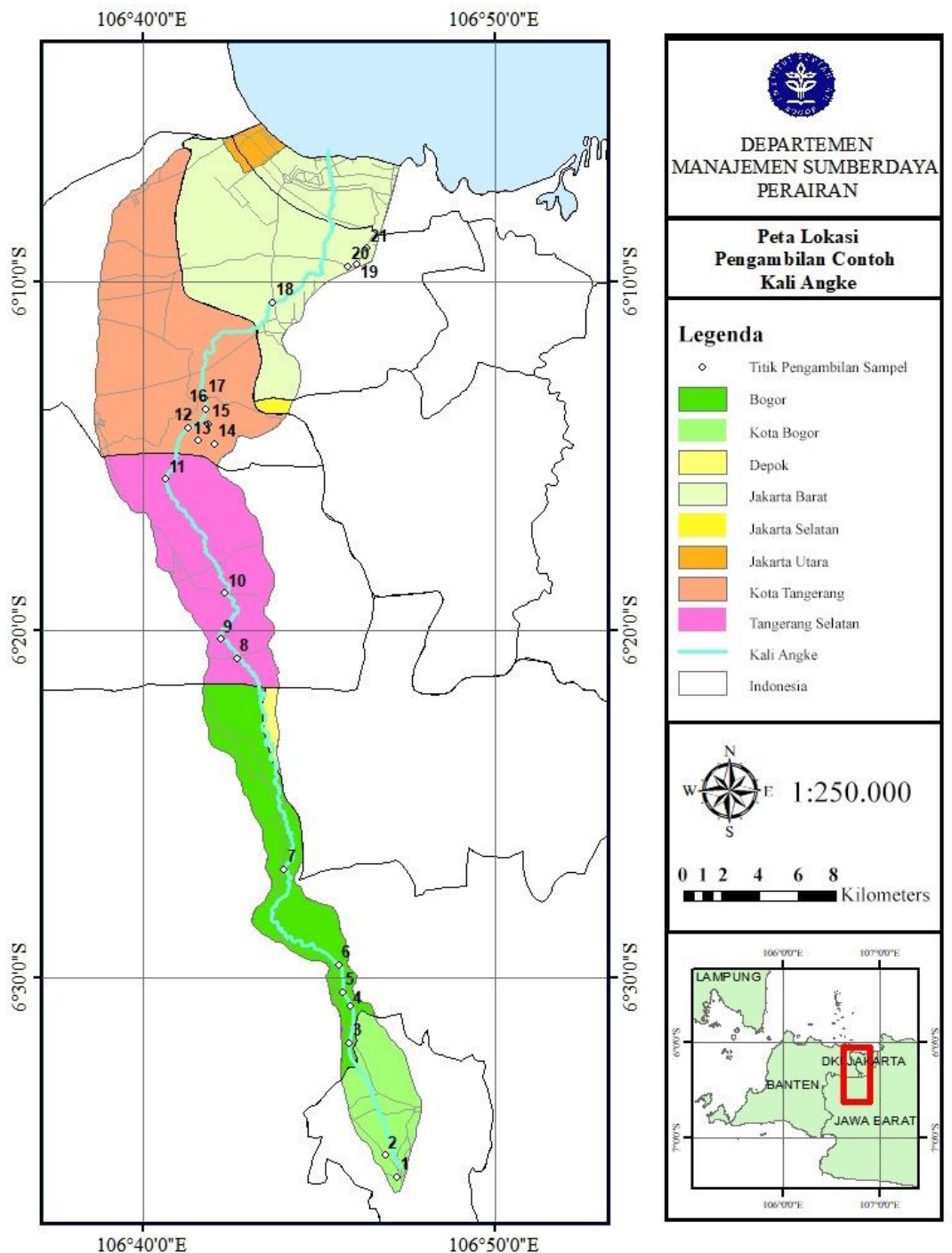

Gambar 1. Lokasi penelitian di Kali Angke.

Tabel 1. Lokasi pemantauan kualitas air Kali Angke.

\begin{tabular}{cll}
\hline Nomor Lokasi & Nama Lokasi & Segmentasi \\
\hline 1 & Pasar Devris & Kota Bogor *Cidepit \\
2 & Lapangan Golf & Kota Bogor *Cidepit \\
3 & PT Kerta Bogor Cahaya & Kota Bogor *Cidepit \\
4 & Jl. Raya Kemang & Kabupaten Bogor \\
5 & Jembatan Perum Bilabong & Kabupaten Bogor \\
6 & Jl. Baru Kemang & Kabupaten Bogor
\end{tabular}




\begin{tabular}{cll}
\hline Nomor Lokasi & Nama Lokasi & Segmentasi \\
\hline 7 & Desa Lebak Wangi & Kabupaten Bogor \\
8 & Hulu Tangsel & Tangerang Selatan \\
9 & Ciater & Tangerang Selatan \\
10 & Lengkong & Tangerang Selatan \\
11 & Hilir Tangsel & Tangerang Selatan \\
12 & Kampung Tajur & Tangerang \\
13 & Jembatan Perum Puri Kartika I & Tangerang \\
14 & Jembatan Perum Duren & Tangerang \\
15 & Jembatan Ciledug Indah & Tangerang \\
16 & Wetan & Tangerang \\
17 & Pondok Maharta & Tangerang \\
18 & Ciledug (Jakarta) & Jakarta Barat \\
19 & Pesing Kali Angke & Jakarta Barat \\
20 & Jl. Daan Mogot & Jakarta Barat \\
21 & Jl. Tubagus Angke & Jakarta Barat
\end{tabular}

*di Kota Bogor Kali Angke disebut sebagai Sungai Cidepit

\subsection{Prosedur analisis data}

Pengumpulan data primer dilakukan melalui pengukuran secara langsung di lapang dan pengambilan contoh air untuk dianalisis di laboratorium. Data primer mencakup parameter in situ yakni suhu, $\mathrm{pH}$, dan DO, serta parameter ex situ meliputi TSS, BOD, dan COD. Pengambilan contoh air berdasarkan data dari Dinas Lingkungan Hidup (DLH) yang mewakili masing-masing segmen dari lokasi penelitian dapat dilihat pada Tabel 2.

Tabel 2. Waktu pengambilan contoh air di Kali Angke berdasarkan DLH.

\begin{tabular}{lll}
\hline \multicolumn{2}{c}{ Waktu Pengambilan Contoh } & \multirow{2}{*}{ Lokasi Pengambilan Contoh } \\
\hline Tahun & Bulan & \\
& September & Tangerang Selatan \\
& Oktober & Kota Bogor, Kabupaten Bogor, dan Jakarta Barat \\
& November & Tangerang \\
& Juni & Kota Bogor \\
& September & Tangerang Selatan \\
& Oktober & Kabupaten Bogor, Tangerang dan Jakarta Barat \\
& Februari & Kabupaten Bogor \\
& Mei & Tangerang Selatan \\
& Juni & Tangerang \\
& Agustus & Jakarta Barat \\
& November & Kota Bogor \\
\hline
\end{tabular}

Parameter kualitas air pada data sekunder meliputi parameter fisika (suhu, TSS, dan TDS), parameter kimia (DO, BOD, COD, $\mathrm{NO}_{2}-\mathrm{N}, \mathrm{NO}_{3}-\mathrm{N}, \mathrm{pH}$, total fosfat, seng, minyak dan lemak, air raksa, dan tembaga) dan parameter biologi (fecal coliform dan total coliform). Alat ukur dan metode analisis kualitas air yang digunakan mengacu pada APHA (2017) (Tabel 3). 
Tabel 3. Metode analisis kualitas air.

\begin{tabular}{lll}
\hline Parameter & Satuan & Alat ukur/Metode \\
\hline Suhu & ${ }^{\circ} \mathrm{C}$ & Temperatur meter/DO-meter \\
TSS & $\mathrm{mg} / \mathrm{L}$ & Neraca Analitik/TSS Dried at $103-105^{\circ} \mathrm{C}$ \\
$\mathrm{TDS}$ & $\mathrm{mg} / \mathrm{L}$ & Neraca analitik/TDS Dried at $180 \pm 2^{\circ} \mathrm{C}$ \\
$\mathrm{DO}$ & $\mathrm{mg} / \mathrm{L}$ & DO-meter \\
$\mathrm{pH}$ & - & Stik pH \\
$\mathrm{BOD}$ & $\mathrm{mg} / \mathrm{L}$ & Alat titrasi/Winkler inkubasi 5 hari \\
$\mathrm{COD}$ & $\mathrm{mg} / \mathrm{L}$ & Spektrofotometer/Closed refluks \\
Nitrat $\left(\mathrm{NO}_{3}-\mathrm{N}\right)$ & $\mathrm{mg} / \mathrm{L}$ & Spektrofotometer/Cadmium reduction \\
Nitrit $\left(\mathrm{NO}_{2}-\mathrm{N}\right)$ & $\mathrm{mg} / \mathrm{L}$ & Spektrofotometer/Sulfanilamide \\
Total Fosfat $\left(\mathrm{PO}_{4}-\mathrm{P}\right)$ & $\mathrm{mg} / \mathrm{L}$ & Spektrofotometer/Ascorbid acid \\
Minyak dan $\mathrm{Lemak}$ & $\mu \mathrm{m} / \mathrm{L}$ & Neraca analitik/Extraction \\
Air Raksa $(\mathrm{Hg})$ & $\mathrm{mg} / \mathrm{L}$ & Spektrofotometer/AAS \\
Tembaga $(\mathrm{Cu})$ & $\mathrm{mg} / \mathrm{L}$ & Spektrofotometer/AAS \\
Seng $(\mathrm{Zn})$ & $\mathrm{mg} / \mathrm{L}$ & Spektrofotometer/AAS \\
Fecal coliform & $\mathrm{MPN} / 100 \mathrm{ml}$ & Most Probable Number \\
Total coliform & $\mathrm{MPN} / 100 \mathrm{ml}$ & Most Probable Number \\
\hline
\end{tabular}
Sumber: APHA (2017)

\subsubsection{Indeks Pencemaran (IP)}

Indeks Pencemaran (IP) merupakan indeks yang dijadikan pedoman dalam penentuan tingkat pencemaran perairan oleh Kementerian Lingkungan Hidup Indonesia berdasarkan KepMenLH Nomor 115 Tahun 2003, dengan menggunakan formulasi sebagai berikut:

$$
I P_{j}=\sqrt{\frac{\left(C_{i} / L_{i j}\right)_{M}^{2}+\left(C_{i} / L_{i j}\right)_{R}^{2}}{2}}
$$

Keterangan:

$\mathrm{IP}_{\mathrm{j}} \quad=$ Indeks Pencemaran untuk peruntukan ke-j

$\mathrm{C}_{\mathrm{i}} \quad=$ Konsentrasi parameter kualitas air ke-i hasil pengukuran

$\mathrm{L}_{\mathrm{ij}} \quad=$ Konsentrasi parameter kualitas air ke-i yang tercantum dalam baku mutu peruntukan ke-j

$\left(\mathrm{C}_{\mathrm{i}} / \mathrm{L}_{\mathrm{ij}}\right)_{\mathrm{M}}=$ Nilai maksimum $\mathrm{C}_{\mathrm{i}} / \mathrm{L}_{\mathrm{ij}}$

$\left(\mathrm{C}_{\mathrm{i}} / \mathrm{L}_{\mathrm{ij}}\right)_{\mathrm{R}}=$ Nilai rata-rata $\mathrm{C}_{\mathrm{i}} / \mathrm{L}_{\mathrm{ij}}$

Nilai nol mewakili kondisi kualitas air terbaik seperti disajikan dalam Tabel 4.

Tabel 4. Penentuan kriteria perairan berdasarkan IP.

\begin{tabular}{cc}
\hline Nilai Indeks Pencemaran (IP) & Kriteria perairan \\
\hline $0 \leq \mathrm{IP}_{\mathrm{j}} \leq 1,0$ & Baik \\
$1,0<\mathrm{IP}_{\mathrm{j}} \leq 5,0$ & Tercemar ringan \\
$5,0<\mathrm{IP} \mathrm{P}_{\mathrm{j}} \leq 10$ & Tercemar sedang \\
$\mathrm{IP}_{\mathrm{j}}>10$ & Tercemar berat \\
\hline
\end{tabular}

Sumber: KepMenLH Nomor 115 Tahun 2003 


\subsubsection{Indeks Canadian Council of Ministers of The Environment (CCME)}

Indeks Canadian Council of Ministers of The Environment yang kemudian disebut Indeks CCME adalah satu dari sebagian indeks kualitas air yang dikembangkan oleh Dewan Menteri Lingkungan Kanada (CCME 2001). Indeks CCME didasarkan pada kombinasi dari tiga faktor, yaitu $\mathrm{F}_{1}$ (scope), $\mathrm{F}_{2}$ (frequency), dan $\mathrm{F}_{3}$ (amplitude), dengan nilai Indeks CCME sebagai berikut:

$$
\mathrm{CCME}=100-\sqrt{\frac{\mathrm{F}^{2}+\mathrm{F}^{2}+\mathrm{F} 3^{2}}{1,732}}
$$

Nilai 1,732 adalah nilai normalitas antara 0 sampai 100 . Nilai nol mewakili kondisi kualitas air terburuk dan nilai seratus mewakili kondisi kualitas air terbaik seperti disajikan dalam Tabel $\mathbf{5}$.

Tabel 5. Penentuan kriteria perairan berdasarkan Indeks CCME.

\begin{tabular}{cc}
\hline Nilai Indeks CCME & Kriteria perairan \\
\hline $95-100$ & Sangat baik \\
$80-94$ & Baik \\
$60-79$ & Cukup baik \\
$45-59$ & Buruk \\
$0-44$ & Sangat buruk \\
\hline
\end{tabular}

Sumber: CCME (2001)

\section{HASIL DAN PEMBAHASAN}

\subsection{Hasil}

\subsubsection{Indeks Pencemaran (IP)}

Hasil perhitungan IP Kali Angke setiap tahunnya memiliki nilai yang berbeda di setiap segmen. Status mutu air Kali Angke tahun 2014 terjadi peningkatan pencemaran pada segmen Kabupaten Bogor, turun pada segmen Tangerang Selatan, dan meningkat hingga segmen Jakarta Barat. Status mutu air pada Kelas I dan II kondisi cemar ringan hingga cemar berat. Status mutu air pada Kelas III dan IV kondisi baik hingga cemar berat (Gambar 2).

Status mutu air Kali Angke tahun 2015 memiliki nilai yang cenderung meningkat ke arah hilir. Hal itu berarti terjadi peningkatan pencemaran dari hulu ke hilir. Status mutu air Kali Angke tahun 2015 (Gambar 3) pada Kelas I, II, dan III kondisi cemar ringan hingga cemar berat, sedangkan Kelas IV kondisi baik hingga cemar berat. 

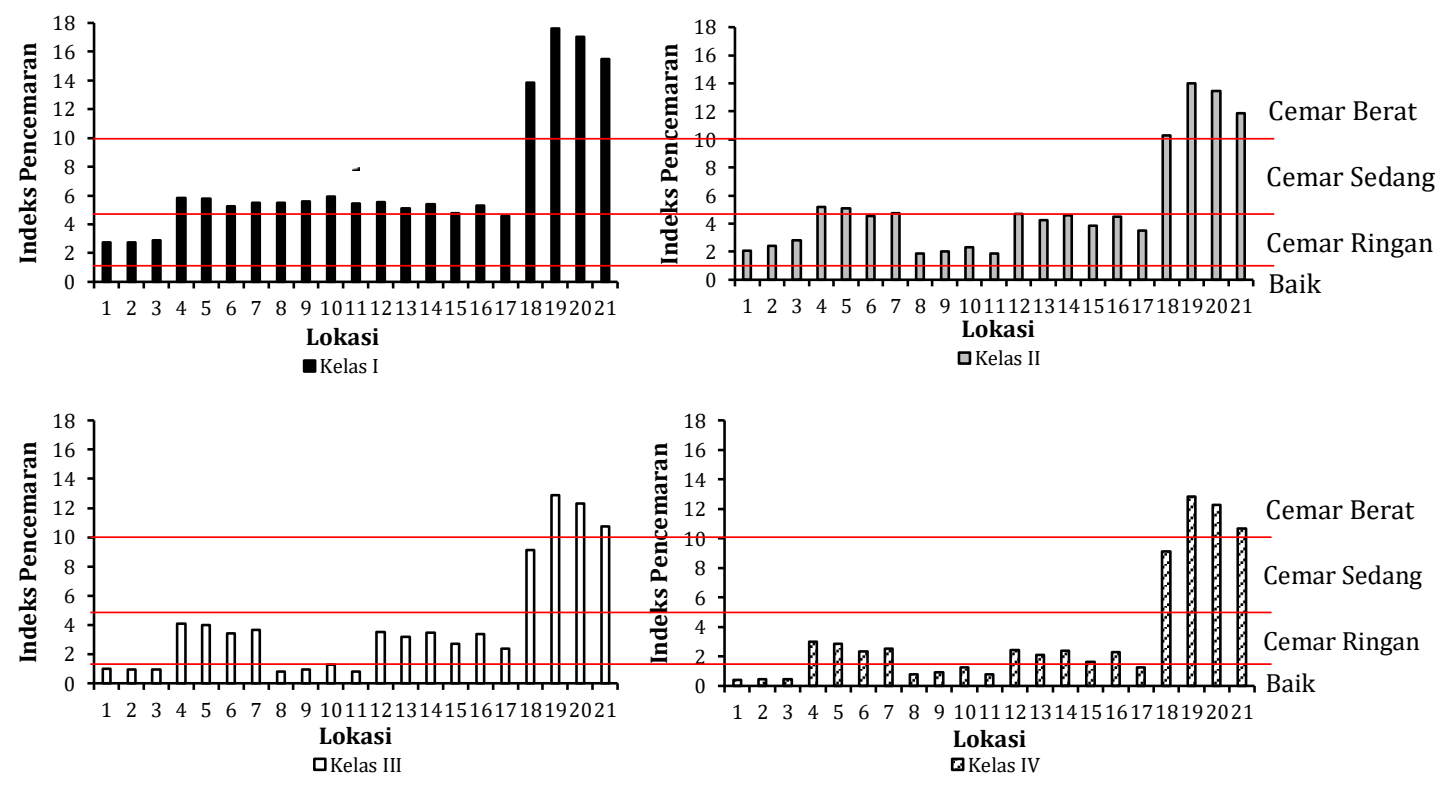

Gambar 2. Nilai Indeks Pencemaran di Kali Angke pada tahun 2014.
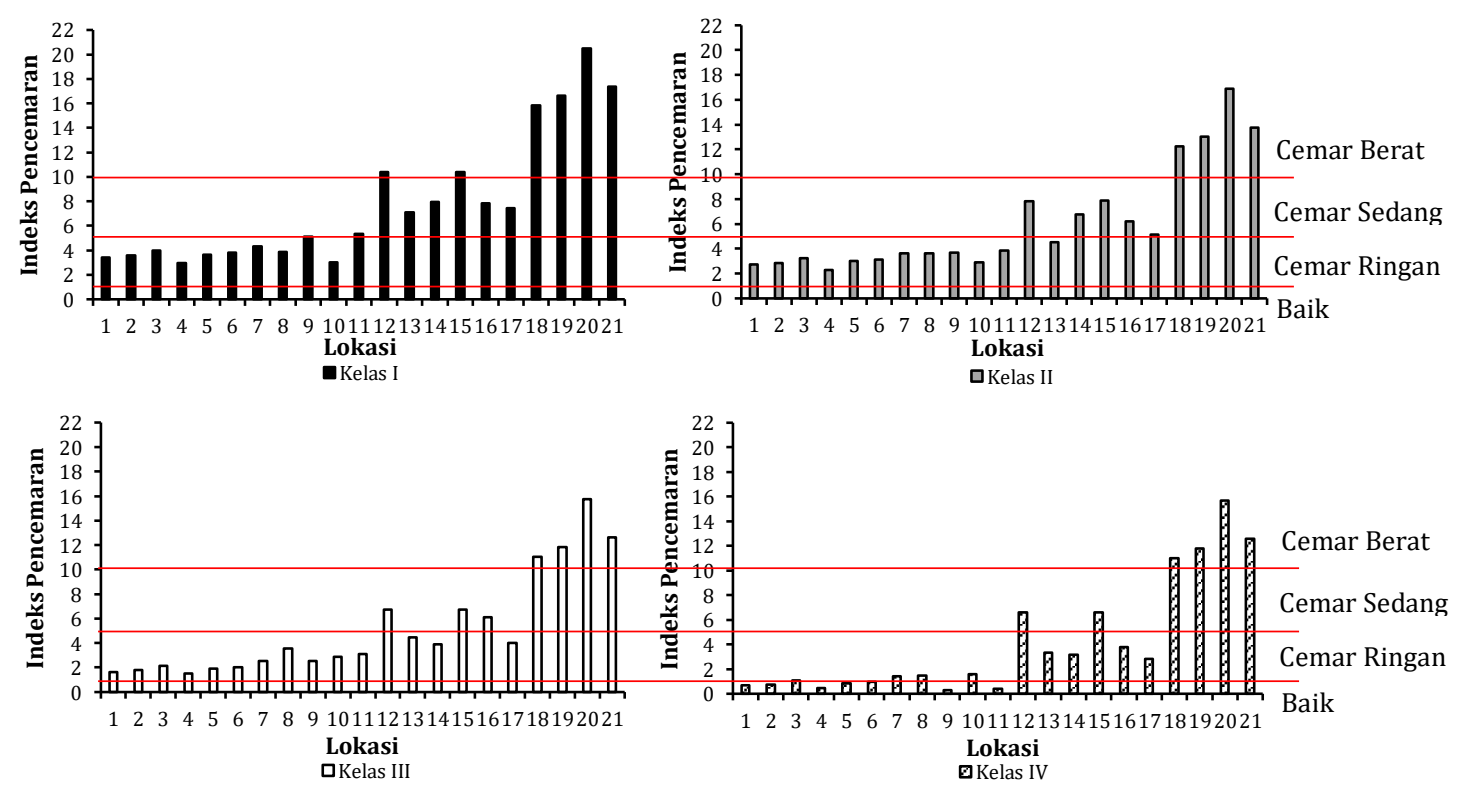

Gambar 3. Nilai Indeks Pencemaran di Kali Angke pada tahun 2015.

Status mutu air Kali Angke tahun 2016 memiliki nilai yang cenderung meningkat ke arah hilir. Namun, pada segmen Tangerang terjadi penurunan pada beberapa titik pengamatan. Gambar 4 menunjukkan status mutu air Kali 
Angke tahun 2016 pada Kelas I, II, dan III kondisi cemar ringan hingga cemar berat, sedangkan Kelas IV kondisi baik hingga cemar berat.
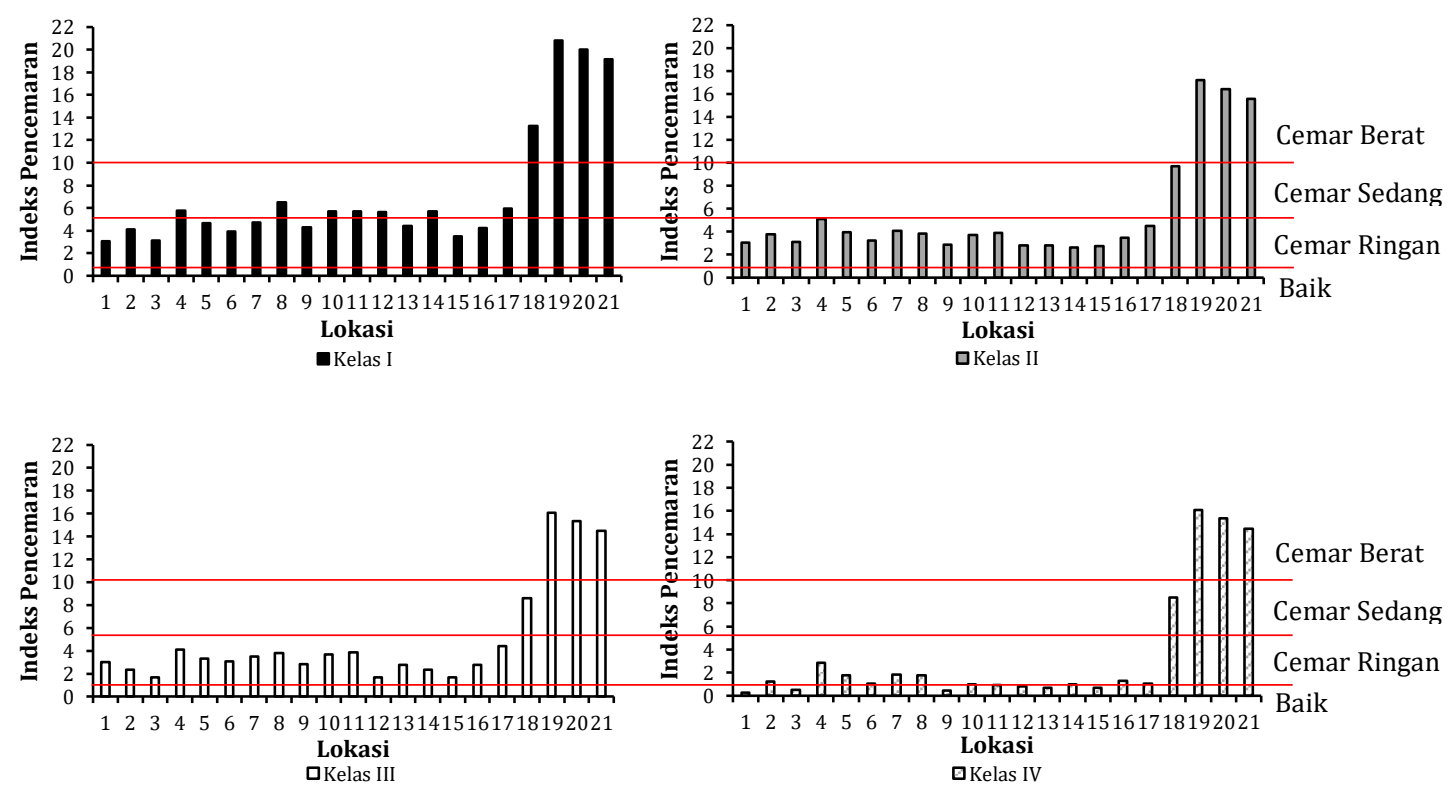

Gambar 4. Nilai Indeks Pencemaran di Kali Angke pada tahun 2016.
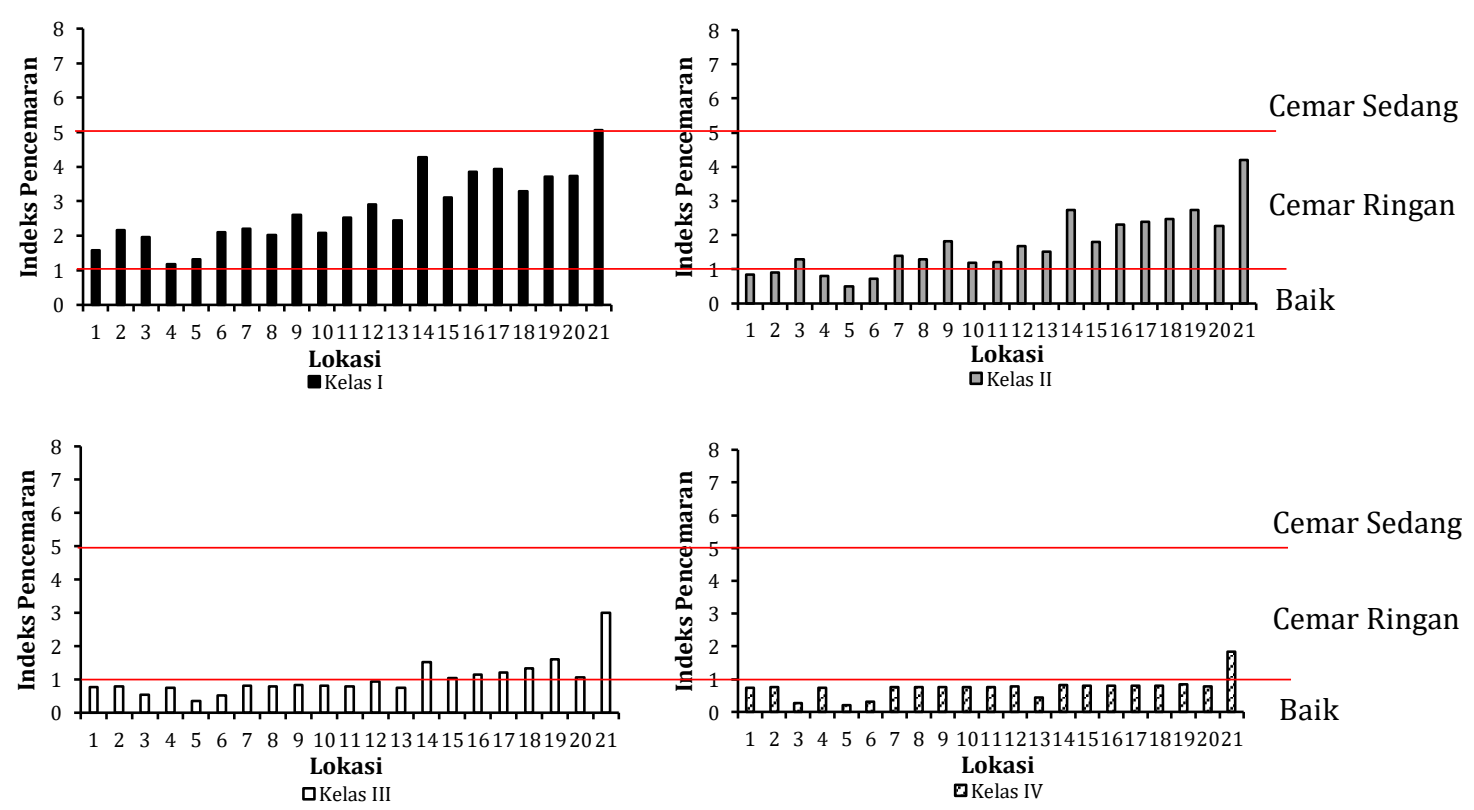

Gambar 5. Nilai Indeks Pencemaran di Kali Angke pada tahun 2017. 
Status mutu air Kali Angke tahun 2017 berdasarkan IP memiliki nilai yang lebih baik dari tahun sebelumnya. Hal tersebut karena pada tahun 2017 parameter yang digunakan dalam perhitungan hanya 6, sedangkan tahun sebelumnya 16 parameter. Status mutu air Kali Angke pada Kelas I dan II dalam kondisi cemar ringan, Kelas III kondisi baik hingga cemar ringan, dan Kelas IV kondisi baik (Gambar 5).

\subsubsection{Indeks Canadian Council of Ministers of the Environment (CCME)}

Hasil perhitungan status mutu air Kali Angke dengan Indeks CCME setiap tahunnya semakin ke arah hilir status mutu air semakin buruk. Status mutu air tahun 2014 (Gambar 6) terjadi peningkatan pencemaran dari Kota Bogor ke Kabupaten Bogor, turun pada segmen Tangerang selatan, meningkat sampai Jakarta Barat. Status mutu air Kali Angke pada Kelas I kondisi buruk hingga sangat buruk, Kelas II kondisi cukup baik hingga sangat buruk, Kelas III kondisi baik hingga sangat buruk dan Kelas IV kondisi sangat baik hingga sangat buruk.

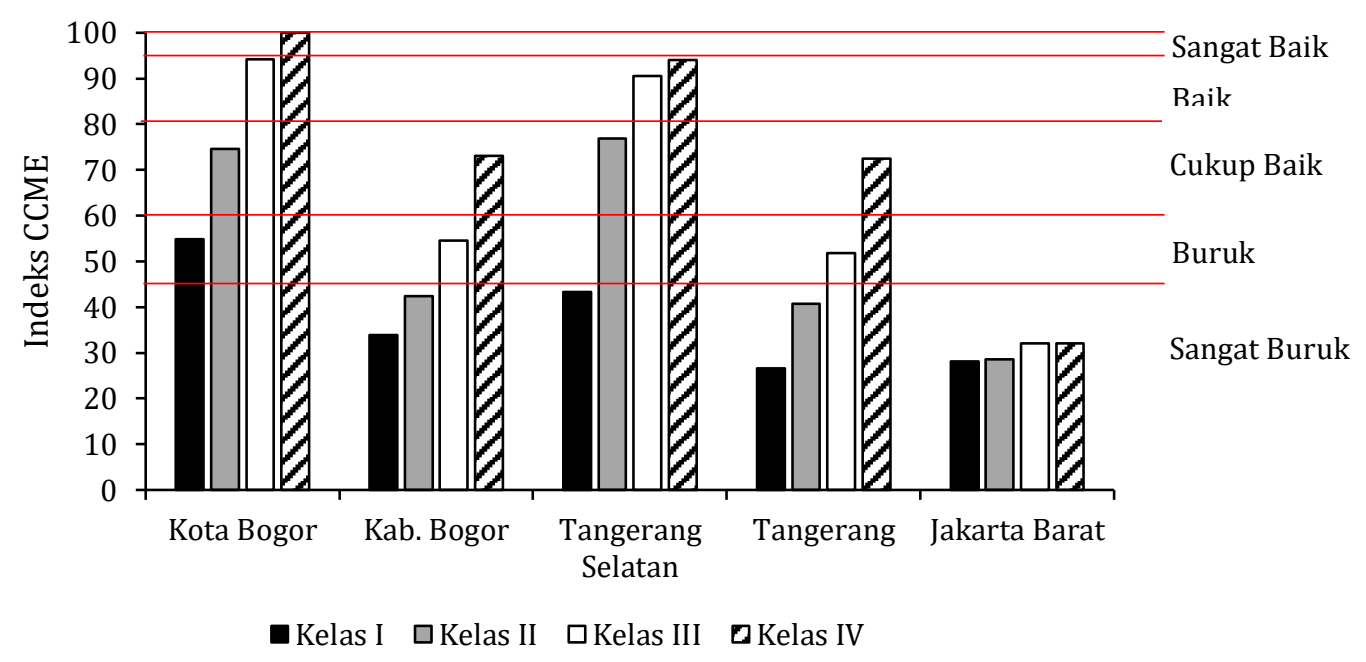

Gambar 6. Nilai Indeks CCME di Kali Angke pada tahun 2014.

Status mutu air Kali Angke tahun 2015 pada Gambar 7 memiliki nilai yang semakin menurun ke arah hilir pada setiap kelas. Hal tersebut berarti terjadi peningkatan pencemaran dari hulu ke hilir. Status mutu air Kali Angke pada Kelas I dan II kondisi buruk hingga sangat buruk, Kelas III kondisi baik hingga sangat buruk, dan Kelas IV kondisi sangat baik hingga sangat buruk. 


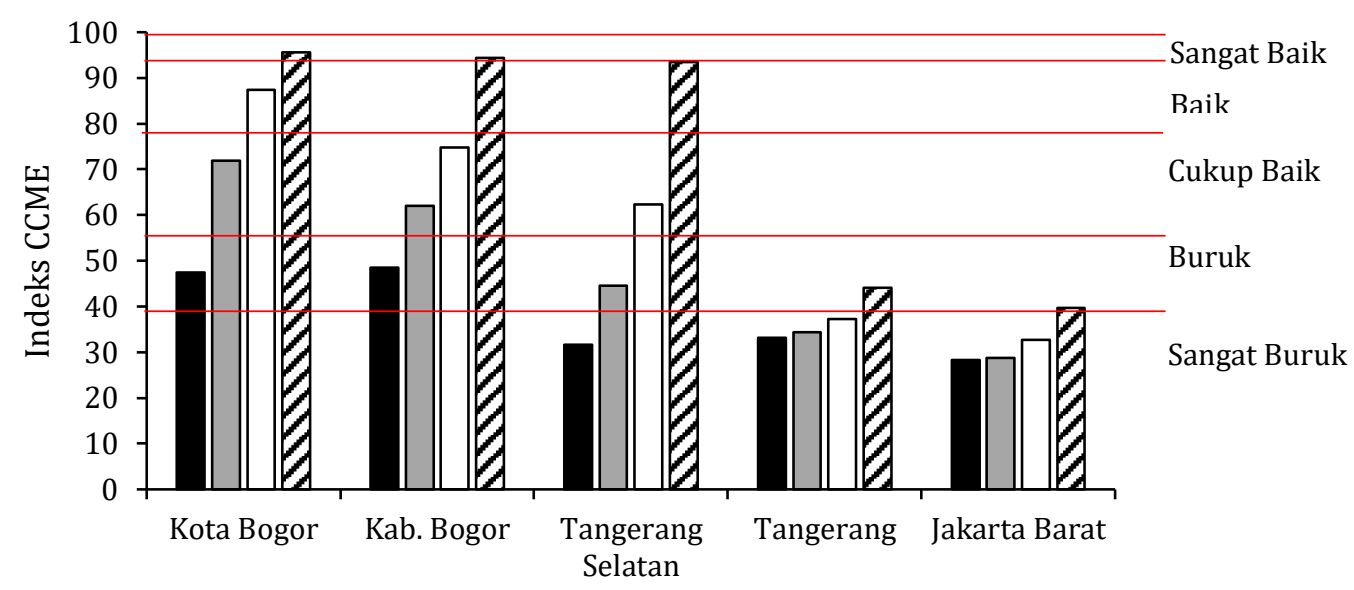

$\square$ Kelas I $\square$ Kelas II $\square$ Kelas III $\square$ Kelas IV

Gambar 7. Nilai Indeks CCME di Kali Angke pada tahun 2015.

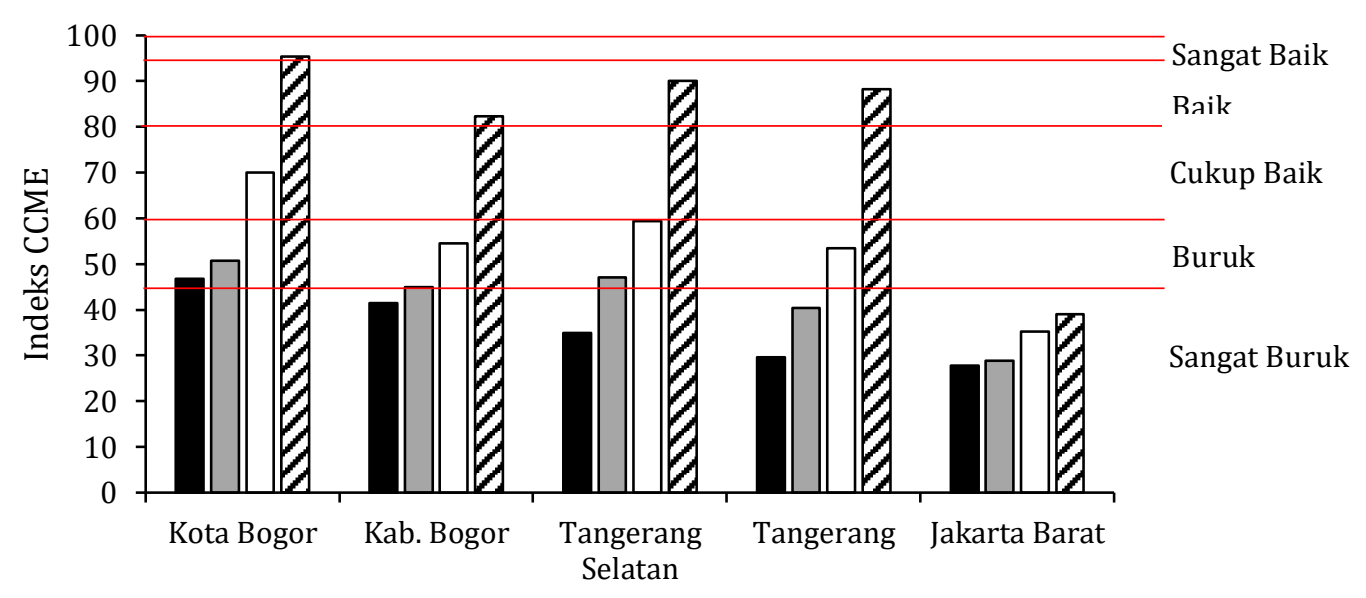

—Kelas I $\square$ Kelas II $\square$ Kelas III $\square$ Kelas IV

Gambar 8. Nilai Indeks CCME di Kali Angke pada tahun 2016.

Status mutu air Kali Angke tahun 2016 memiliki fluktuasi peningkatan dan penurunan pencemaran setiap segmen yang sama dengan tahun 2014. Status mutu air Kali Angke pada Kelas I dan II kondisi buruk hingga sangat buruk, Kelas III dan IV kondisi baik hingga sangat buruk (Gambar 8). 


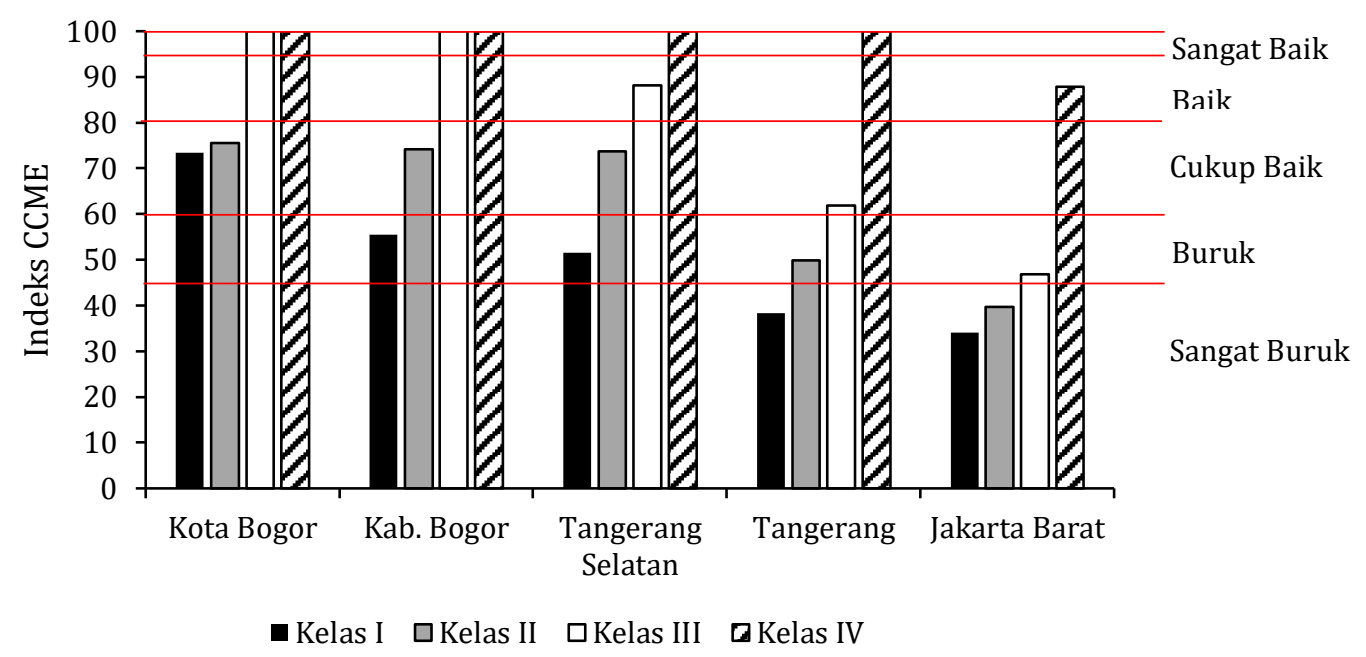

Gambar 9. Nilai Indeks CCME di Kali Angke pada tahun 2017.

Gambar 9 menunjukkan status mutu air tahun 2017 semakin ke arah hilir kondisi status mutu air Kali Angke semakin cemar pada setiap kelasnya. Status mutu air Kali Angke pada kelas I dan III kondisi cukup baik hingga sangat buruk, kelas III kondisi sangat baik hingga buruk, serta kelas IV kondisi sangat baik kecuali Jakarta Barat.

\subsection{Pembahasan}

Kali Angke adalah sungai yang berhulu di Bogor dan berhilir di Muara Angke, Jakarta Barat. Kualitas air di Kali Angke dipengaruhi oleh kegiatan manusia seperti pemukiman, industri, pertanian, dan peternakan. Suhu di Kali Angke cukup bervariasi dari hulu ke hilir di setiap tahunnya dan cenderung meningkat pada tahun 2017. Suhu di perairan dipengaruhi oleh musim, lintang, waktu dalam hari, sirkulasi udara, penutupan awan dan aliran, paparan sinar matahari, serta kedalaman air (Verawati 2016). Suhu pada dasarnya memiliki peran penting bagi reaksi kimia dan biologi tertentu yang terjadi di air dan organisme (Effendi et al. 2015).

Status mutu air Kali Angke ditentukan dengan IP dan Indeks CCME. Kedua indeks ini didasarkan pada perbandingan parameter kualitas air hasil pengukuran dengan standar baku mutu air. IP dan Indeks CCME dapat mencerminkan status mutu air pada berbagai jenis perairan, tergantung pada ketersediaan standar baku mutu peraturan masing-masing perairan. Penggunaan indeks kualitas air dapat meningkatkan pemahaman masalah kualitas air dengan mengintegrasikan data kualitas air yang kompleks menjadi 
skor yang menggambarkan status mutu air dan mengevaluasi tren kualitas air (Hamlat et al. 2014).

Berdasarkan hasil perhitungan IP dan CCME dengan 16 parameter yang didata pada tahun 2014, 2015, dan 2016, Kali Angke cenderung mengalami peningkatan pencemaran setiap tahunnya. Status mutu air Kali Angke dari tahun ke tahun semakin ke arah hilir kondisinya semakin cemar. Jika dibandingkan dengan baku mutu air Kelas I dan II, maka sudah tidak memenuhi peruntukkannya, sehingga dibahas dengan membandingkan pada Kelas III. Status mutu air pada kelas III menurut IP yaitu segmen Kota Bogor pada kondisi baik, Kabupaten Bogor hingga Tangerang kondisi cemar ringan, dan Jakarta Barat kondisi cemar berat. Kecenderungan memburuknya kualitas air sungai di bagian hilir berkaitan erat dengan semakin padatnya pemukiman di sepanjang Daerah Aliran Sungai (DAS) (Effendi et al. 2018a; Effendi et al. 2018b). Akan tetapi, berdasarkan Indeks CCME segmen Kota Bogor dalam kondisi baik, Kabupaten Bogor hingga Tangerang kondisi buruk, dan Jakarta Barat sangat buruk. Jika dilihat secara umum, maka berdasarkan IP menunjukkan status cemar ringan dan Indeks CCME menunjukkan status buruk.

Status mutu air Kali Angke pada tahun 2017 menggunakan 6 parameter dengan IP menghasilkan status mutu baik hingga cemar ringan pada kelas III. Akan tetapi, dengan Indeks CCME hasil setiap segmen berbeda, yaitu dari sangat baik hingga buruk. Jika dibandingkan dengan tahun 2016 dengan parameter yang sama (6 parameter), maka terjadi penurunan tingkat pencemaran pada tahun 2017 baik dengan IP ataupun Indeks CCME. Hasil perhitungan IP dengan menggunakan 6 parameter menunjukkan status mutu air yang lebih baik dibandingkan dengan 15 parameter. Semakin banyak parameter kualitas air yang diukur, maka semakin banyak parameter yang teridentifikasi tidak memenuhi baku mutu, sehingga membuat hasil IP semakin buruk status mutu airnya.

Segmen Jakarta Barat baik dalam perhitungan IP atau Indeks CCME selalu memiliki status mutu air yang paling buruk. Hal tersebut karena sungai pada bagian hilir semakin banyak mendapat masukan bahan pencemar. Jika ditinjau dari kualitas airnya, segmen Jakarta Barat memiliki kualitas air yang secara umum melebihi baku mutu air. Pada hasil perhitungan IP sangat dipengaruhi oleh parameter bakteri. Adanya parameter bakteri yakni Fecal coliform dan Total coliform yang menjadi penyebab signifikan buruknya status mutu air (Effendi 2003; Saraswati et al. 2014). Hal ini karena besaran jumlahnya sangat signifikan yaitu mencapai ratusan ribu hingga jutaan bakteri MPN/100 ml airnya. Akan tetapi, pada Indeks CCME dengan atau tanpa parameter bakteri hampir memiliki hasil yang sama sesuai dengan kondisi perairan. Ketika perairan menunjukkan 
kondisi buruk baik secara fisik dan kimia, maka hasil Indeks CCME pun dalam kondisi buruk.

Menurut Lumb et al. (2006) CCME merupakan metode paling sensitif merespon dinamika mutu air, dengan sedikit atau banyak parameter, dengan dan tanpa parameter bakteri. Perhitungan Indeks CCME lebih memperhatikan banyak aspek. Selain memperhatikan rasio nilai parameter dengan baku mutu, Indeks CCME juga memperhatikan banyaknya parameter yang melebihi baku mutu dan banyaknya hasil uji yang melebihi baku mutu. Menurut Hamlat et al. (2014), Indeks CCME adalah indeks yang paling sesuai karena fleksibilitasnya dalam memilik parameter serta memodifikasi tujuan yang harus dipenuhi.

Akan tetapi, IP dihitung dengan mempertimbangkan rasio konsentrasi suatu parameter dengan baku mutunya $\left(\mathrm{C}_{\mathrm{i}} / \mathrm{L}_{\mathrm{i}}\right)$ maksimum dan rerata rasio sejumlah kualitas air. IP juga hanya menggunakan single data sedangkan Indeks CCME dengan banyak data, sehingga IP dapat dikatakan data kondisi sesaat. Menurut Sahabuddin (2014), perbedaan hasil juga dapat disebabkan oleh perbedaan penentuan nilai skor, IP menggunakan rentang 0 hingga lebih dari 10, sedangkan Indeks CCME memiliki rentang 0 sampai 100. Indeks CCME merupakan metode paling tepat dalam menganalisis mutu air di berbagai negara termasuk Indonesia dengan tingkat efektivitas dan sensitivitas lebih tinggi dibanding metode lain, serta penggunaan jumlah dan jenis parameter yang fleksibel (Romdania et al. 2018).

\section{KESIMPULAN DAN SARAN}

\subsection{Kesimpulan}

Tingkat pencemaran di Kali Angke semakin meningkat dari hulu ke hilir dan tahun 2014 sampai 2016 menunjukkan peningkatan, kemudian menurun pada tahun 2017. Status mutu Kali Angke tergolong cemar ringan menurut IP dan tergolong buruk menurut Indeks CCME pada kelas III. Status indeks kualitas air CCME lebih mewakili kondisi perairan daripada Indeks Pencemaran.

\subsection{Saran}

Perlu adanya peraturan yang mengatur mengenai peruntukan Kali Angke sebagai upaya perbaikan dalam pengelolaan Kali Angke. Serta perlu adanya monitoring data kualitas air secara berkala.

\section{DAFTAR PUSTAKA}

Ali A, Soemarno dan Purnomo M. 2013. Kajian kualitas air dan status mutu air Kali Metro di Kecamatan Sukun, Kota Malang. Jurnal Bumi Lestari 13(2):265-274. 
[APHA] American Public Health Association. 2017. Standard methods for the examination of water and waste water 23rd edition. American Public Health Association; American Water Works Association; Water Environment Federation. Washington DC.

[CCME] Canadian Council of Ministers of the Environment. 2001. Canadian water quality guidelines for the protection of aquatic life: CCME water quality Index 1.0, User's Manual. CCME. Winnipeg.

Cordova MR dan Riani E. 2011. Konsentrasi logam berat (Hg, Cd, Pb) pada air dan sedimen di muara Sungai Angke, Jakarta. Jurnal Hidrosfir Indonesia 6(2):107-112.

Effendi H. 2003. Telaah kualitas air: bagi pengelolaan sumberdaya dan lingkungan perairan. Yogyakarta (ID): Kanisius.

Effendi H, Romanto and Wardiatno Y. 2015. Water quality status of Ciambulawung River, Banten Province, based on pollution index and NSFWQI [Proceeding]. Procedia Environmental Sciences 24:228-237.

Effendi H, Muslimah S and Permatasari PA. 2018a. Relationship between land use and water quality in Pesanggrahan River [Proceeding]. Procedia Environmental Sciences 149 012022. doi: 10.1088/1755-1315/149/1/ 012022.

Effendi H, Permatasari PA, Muslimah S and Mursalin. 2018b. Water quality of Cisadane River based on watershed segmentation [Proceeding]. Procedia Environmental Sciences 149 012023. doi: 10.1088/1755-1315/149/1/ 012023.

Hamlat A, Tijani AE, Yebdri D and Guidoum ME. 2014. Water quality analysis of reservoirs within western Algeria catchment areas using water quality index CCME WQI. Journal of Water Supply 63(4):311-325.

Imroatushshoolikhah, Purnama IS dan Suprayogi S. 2014. Kajian kualitas air Sungai Code Provinsi Daerah Istimewa Yogyakarta. Majalah Geografi Indonesia 28:23-32.

KepMenLH (Keputusan Menteri Lingkungan Hidup) Nomor 115 Tahun 2003 tentang pedoman penentuan status mutu air.

Lumb A, Halliwell D and Sharma T. 2006. Application of CCME water quality index to monitor water quality: a case of the Mackenzie River Basin, Canada. Environmental Monitoring and Assessment 113:411-429.

Pasisingi N, Pratiwi NTM dan Krisanti M. 2014. Kualitas perairan Sungai Cileungsi bagian hulu berdasarkan kondisi fisik-kimia. Depik 3(1):56-64.

Romdania Y, Herison A, Susilo GE dan Novilyansa E. 2018. Kajian penggunaan metode IP, STORET, dan CCME WQI dalam menentukan status kualitas air. Jurnal Spatial 18(1): 1-13. 
Sahabuddin H, Harisuseno D dan Yuliani E. 2014. Analisis status mutu air dan daya tampung beban pencemaran Sungai Wanggu, Kota Kendari. Jurnal Teknik Pengairan 5(1):19-28.

Saraswati S, Sunyoto, Kironoto B dan Hadisyanto S. 2014. Kajian bentuk dan sensitivitas rumus indeks PI, STORET, CCME untuk penentuan status mutu perairan sungai tropis di Indonesia. Jurnal Manusia dan Lingkungan 21(2):129-142.

Tjampakasari CR and Wahid MH. 2008. Water quality of Angke River: microbiological point of view. Med J Indonesia 17(2):82-88.

Verawati. 2016. Analisis kualitas air laut di Teluk Lampung [Tesis]. Universitas Lampung. Bandar Lampung.

Wiwoho. 2005. Model identifikasi daya tampung beban cemaran sungai dengan QUAL2E (studi kasus Sungai Babon) [Tesis]. Universitas Diponegoro. Semarang. 